\title{
LONG-TERM IMPACTS OF THE 1997 FLOODS IN THE MORAVA RIVER BASIN
}

\begin{abstract}
A. Vaishar, P. Hlavinková, K. Kirchner, J. Lacina: Long-Term Impacts of the 1997 Floods in the Morava River Basin. Geografie - Sborník CGS, 105, 2, pp. 141 - 154 (2000). In 1997 disastrous floods, unparalleled since meteorological and climatic measurements have been carried out, took place in the catchment of the Morava river and other Moravian rivers. The long-term impacts of the above-mentioned flood event on the landscape and society have been examined in four selected model areas with different natural and economic characteristics. Within the natural system, the long-term impacts include changes in riverbeds, landslides and changes in the biota. Within the social system, the most significant adverse impacts include the long-term damage to the psychical health of those affected by the flood. The main causes of the flood damage are connected with the formation of the settlement pattern during the period of industrialisation and urbanisation. The main methods of flood protection include the relocation of structures outside inundated areas, technical control and the adaptation to flood risks.

KEY WORDS: natural risks - floods - the Morava river - long-term impacts.
\end{abstract}

This contribution has been prepared as part of the grant project of the Grant Agency of the Academy of Sciences of the Czech Republic Nr. IAA3086903 "Floods, Landscape and People in the Morava River Basin”

\section{Introduction}

This contribution discusses the long-term impacts of floods, which took place in the catchment of the Morava river in July 1997. The cause of these floods is apparent: extreme precipitation occurred across a relatively large area of the Morava river basin. The primary damage was calculated and evaluated. The death tolls reached 50, the material damage was estimated at about 60 bil. Kč: 538 towns and villages were affected, 2,151 dwellings were destroyed, 16,500 dwellings were seriously damaged, just as $946 \mathrm{~km}$ of railways and $580 \mathrm{~km}$ of roads. 100,000 ha of agricultural land were flooded, with losses in crops and livestock. Water and soil were polluted since wastewater plants were flooded and oil products and various other harmful industrial substances were washed up. What is important to note is that the epidemiological situation could be kept under control.

Almost all the direct damage caused to the housing stock and infrastructure has already been restored or the restoration is drawing to an end. The damage to economy can hardly be evaluated since the time of the floods overlaps that of the beginning of economic recession in the Czech Republic. Paradoxically, the flood event also had positive aspects. These include the mobilisation of social potential, the renewal of infrastructure in a modern framework and the restoration of the historical memory of the population. Experts from 


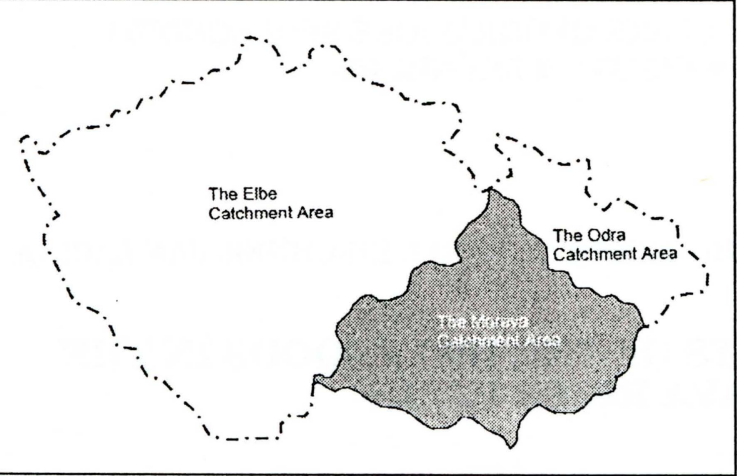

Fig. 1 - The Morava river basin in the framework of the Czech Republic

hydrometeorological and water institutions and from universities evaluated a series of partial aspects of this event. We, as geographers, are interested in the regional aspects of the problem and in the relation between natural phenomena and the social system.

After the primary evaluation of the event (Munzar, Ondráček, Táborská 1997), we have focused our attention on the longterm impacts of the floods, which started to manifest themselves roughly two years after the event. These impacts can be observed in both the landscape and the human system. Research is being undertaken in four model areas, which represent different types of affection in different parts of the Morava river basin (Vaishar 1999a). Some research is being carried out in other regions, too. The design team is composed of physical and human geographers. Also methods of behavioural geography, such as conducted interviews and inquiry surveys, have been adopted.

\section{The Essence of Floods and their Impacts in the Individual Model Regions}

The model region Hanušovice/Jindřichov lies in the upper reach of the Morava river at its confluence with the rivers Branná, Krupa, Hanušovický potok (Hanušovice brook) and others. The cores of the present-day settlements, together with the main roads and industrial plants, are embedded in the relatively deep and narrow valleys of the watercourses. As a result of the compulsory transfer of Germans after 1945, almost a complete exchange of population took place here, which led to disrupting the continuity of the historical memory in relation to floods. At the very beginning of the flood, the region was hit by rain torrents reaching a high speed. The velocity of the stream, together with the amount of transported materials and debris, had significant devastating power. The area was cut off from the rest of the world for a few days. The flood inflicted serious damage on the infrastructure, housing and the paper works industry in Jindřichov. Despite the extreme severity of the flood, only one direct human casualty was recorded.

The model region Mikulůvka/Bystřička/Růždka lies in the catchment of the Bečva river and its tributaries. The settlement is rural to marginal in character, with a population largely dependent on commuting to work to the biggest centres in the Vsetín district. In 1912, a water reservoir was built on the small river Bystřička whose primary purpose was to control floods, with recreation having developed as its secondary purpose. As a result of extreme rains in July 1997, the vacant retention capacity of the water reservoir, about 2,5 million $\mathrm{m}^{3}$ before the flood, was filled for the first time and the water 


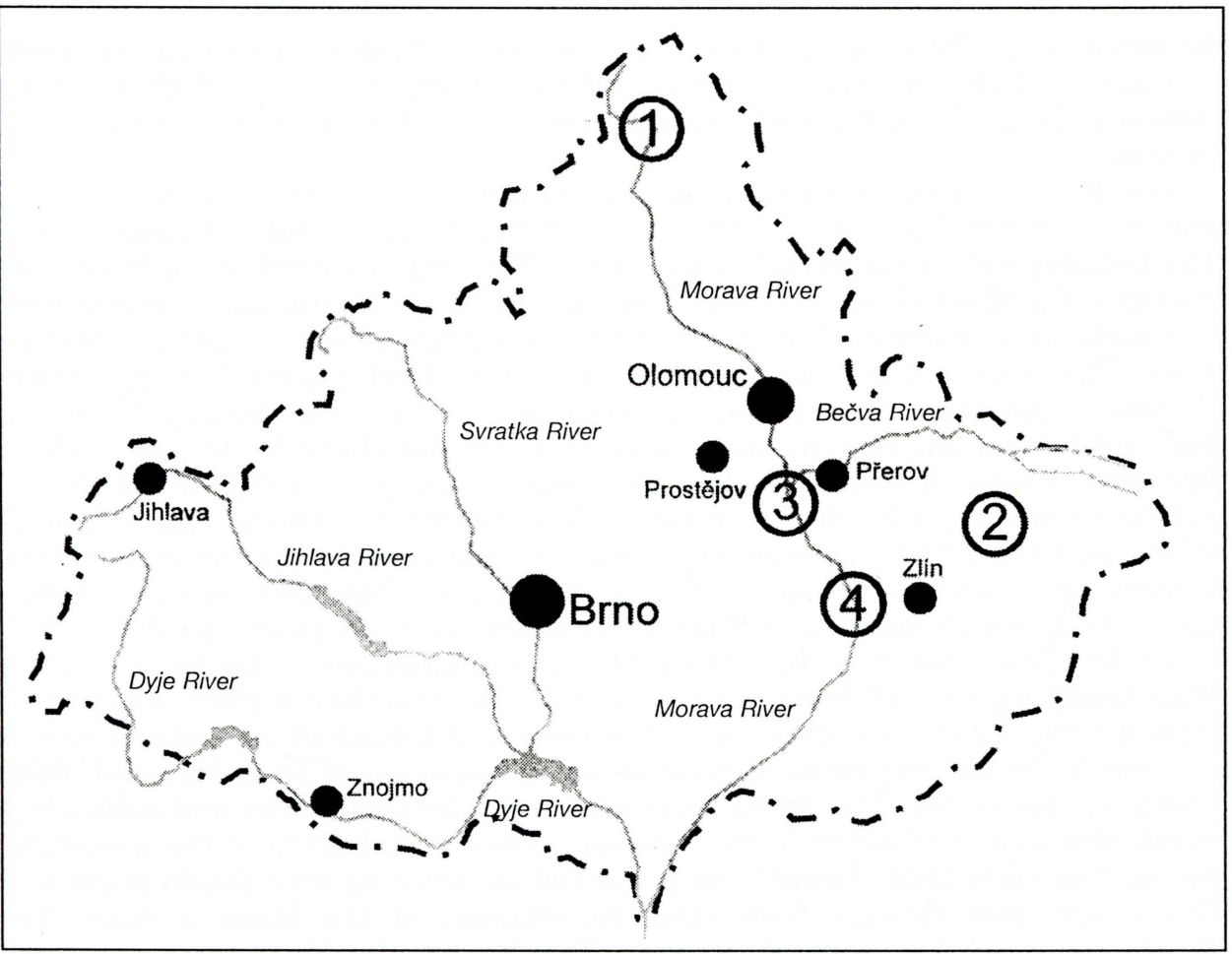

Fig. 2 - Selected Model Regions. Model areas: 1 - Hanušovice / Jindřichov, 2 - Bystřička / Mikulůvka / Růždka, 3 - Bochoř / Troubky / Vlkoš, 4 - Otrokovice.

flowed over the dam. The extremely high flow in the Bystřice river amounted up to $170 \mathrm{~m}^{3} / \mathrm{s}$ (with the normal flow at the estuary into the Bečva river being $1,05 \mathrm{~m}^{3} / \mathrm{s}$ ), and the flood wave reached up to $130 \mathrm{~cm}$. Thanks to the fact that the water reservoir took 30 hours to fill up, the population could warned in time so that there was not high death toll. The occurrence of frequent and extensive landslides that caused serious damage to the infrastructure and housing was the specific consequence of the catastrophe.

The model region Bochoř/Troubky/Vlkoš lies in a fertile flood plain not far from the confluence of the Morava and Bečva rivers. It is a flatland area, with the maximum differences in altitude ranging from 5 to 7 meters. The settlement is of rural character, with farming still having a major share in the economic structure. A large portion of the housing stock, or at least the cores of the structures - reconstructed and extended in the course of time, was built of cob, a popular building material at the end of the 19th century and the beginning of the 20th century. The fact that the flood did not come from the direction of the Morava river, as expected, but from the more distant Bečva river, which breached its embankments downstream of the district town of Prrerov, gave rise to a specific problem characteristic of the 1997 flood situation. The water masses came over the watershed divide and were running in several streams concentrated in slight terrain depressions. These streams gradually joined, thus multiplying their devastating strength. Having no significant elevation, the landscape did not provide any possibility 
for protection. The cores of the structures made of cob broke down and their extensions, built of other materials, then collapsed on top of them. Nine inhabitants of the village of Troubky lost their lives in the ruins of their houses.

The model region Otrokovice includes a town with a population of 20,000 and its surroundings at the confluence of the Morava and Dřevnice rivers. The housing estate Bahňák, built in the 1930s near the combine of Bata, was particularly affected by the flood. The idea to locate this housing estate here was motivated, among other things, by the low price of land in this inundation area. The area accommodates important industrial plants (among others Barum, a company manufacturing tyres, and the aircraft factory Moravan) and residential blocks consisting of typical functionalistic buildings made of fair-face bricks. A flood affected the area as early as 1930, which led to extensive measures having been taken. The Tresný hill on the opposite bank of the Morava river was washed down into the area of the housing estate, increasing its level by 2 meters. Furthermore, the whole area was thoroughly embanked, which seemed sufficient for more than 60 years. In July 1997, when the Dřevnice river first breached its embankments, the Morava river then broke up the left-bank dike near Kvasice, and then a flood wave came from a large flood lake after the Bečva river had breached its embankments, and lastly the railway embankment between the towns of Kroměřiž and Hulín had been destroyed. The water level was rising for three days and achieved a maximum height of $3,5 \mathrm{~m}$ in the residential zones and $4,5 \mathrm{~m}$ in the industrial zones. The dikes that should have protected the town against floods prevented the water from flowing back into the channel of the Morava river. The flooding lasted for several weeks. Thanks to the fact that the local government managed to withstand pressure to accelerate the receeding flow by breaking through the dikes, no flood wave arose so that it was not necessary to break down a single residential building. However, damage to the infrastructure and industrial and private property was recorded.

The hitherto knowledge of the flood suggests that the major cause of the damage inflicted by the flood included a complex of problems associated with the changes carried out in the pattern of settlement during industrialisation and urbanisation, that being in the second half of the 19th century and the first half of the 20th century for Moravia (Vaishar 1996b). At that time, a great number of people began to settle in the flood plain areas, with flood protection having been solved by technical measures, namely by constructing water reservoirs and dikes. As a result, the historical memory of the population in relation to flood hazard began to disappear. Also the behaviour of people and firms during floods was connected with it to a great extent, as was the minimum preparedness of the people and the rescue system. The era of socialism had only intensified these problems in many respects.

Discussions are under way about the decline in the retention capability of the landscape. However, it appears that this issue is of more common concern, or less, in relation to smaller and relatively regular floods, as well as in relation to the course of time of flood waves. It is apparent that the extreme precipitation in July 1997 exceeded the theoretical maximum retention capacity of the landscape several times, which could have retarded the coming of the flood by several hours at most. In relation to the natural environment, the problem lies, more or less, in the fact that earlier, floods would be a natural, regularly recurring phenomenon, which played a major part in landscape management. The changes brought about by industrialisation and 
urbanisation interrupted this process. Therefore, obtaining knowledge of the course and impacts of the floods that took place in Moravia in historical times is also significant (Munzar 1998).

\section{Long-term impacts of the floods on the natural system}

The extreme precipitation and the extensive floods in July 1997 had instantaneous impacts on and implications in the natural sphere of the landscape, and caused direct damage. A series of these impacts brought about changes in the natural sphere. These changes have not been amended and will have long-term effects. In many cases, the return to the original character of the relief or ground cover is no longer possible even if the implications have been removed (e.g. through levelling the ground of the flood plain, reclamation of damaged river banks etc.), and the changes will remain permanent. We will discuss those changes in the abiotic and biotic sectors of the natural sphere of the landscape that occurred immediately as a result of the floods, and may continue to exist for a long period of time. These changes will be the subject of further research.

The heavy precipitation saturated the upper layers of the soil and rock profile in mountainous parts of the upper section of the Morava river (Sudetenland) and also in the Carpathian section of the Morava river basin (the Bečva river, the Outer Western Carpathians). The high flows caused a flood situation not only in the upper sections of the catchment but also in the middle and lower sections. The saturation of mountain massifs led to the activation and rise of slope deformations. A less extensive occurrence of slope deformations was recorded in the area of Sudetenland where the geological conditions for their rise are less favourable. For example, an extensive landslide was recorded near Hanušovice (over $100 \mathrm{~m}$ wide). The chief causes of the rise of slope processes in this area included lateral river erosions and wetting (Vít, Aichler, Pecina 1998).

A great amount of slope processes (particularly landslides and ground streams) was activated in the area formed by the flysch complexes in the Outer Western Carpathians (the mountainous part of the catchment of the Bečva river) where the geological conditions for the development of slope deformations are very favourable. In the district of Vsetín, the activity of the slope deformations locally reached almost disastrous effects (Kirchner, Krejčí, 1998). In the catchment of the Rožnovská Bečva river, a series of landslides was activated by the lateral erosion of watercourses. Smaller watercourses were frequently under the threat of their streambed being dammed up (e.g., the Solanecký potok /Solanecký brook/). South of Rožnov p. R., the lateral erosion caused the movement of a landslide of a length of up to $20 \mathrm{~m}$ collided into the streambed of the Rožnovská Bečva river (Kirchner, Krejčí, 1998a). Extensive ground streams and landslides affected the valley slopes of the Bystřička water reservoir, bringing a great amount of fine-grain material into the reservoir. This material accumulated together with the flood sediments. A series of hazardous landslides has already been cleared, however the majority of slope deformations could be reactivated under favourable conditions and their activity is long-term.

The flood flows in the upper sections of the catchment of the Morava river and the Bečva rivers, its Carpathian tributary, caused an intensive erosion in riverbeds and on valley bottoms translocating and depositing a great amount 
of fluvial sediments. They flooded large areas and fine-grain sediments settled in the lower flatland sections of the catchment area. An intensive erosion in riverbeds (lateral and deep erosion) occurred in the upper section of the catchment of the Morava river (Sudetenland), soil losses also took place on the flood plain surface. According to Gába (1999), the lateral erosion in this area was typically about $10 \mathrm{~m}$, with a maximum of up to $90 \mathrm{~m}$. Also new river beds arose in this area, while the old ones were sedimented. A significant rectification of the riverbed of the Morava river took place in Hanušovice, a relocation of streambeds occurred frequently as a result of the flood. Also the effects of erosion manifested themselves significantly (erosion rills and gullies of a depth of up to $3 \mathrm{~m}$ arose on mountain slopes). The effects of erosion were significant also in the rise of new streambeds in the flood plain. Through retrogressive erosion, Krupá, a small river, recessed into the flood plain sediments by $2,5 \mathrm{~m}$. Also frequent sedimentation on the flood plain surface was characteristic of this area (the gravel bank locally reached a thickness of 2 to 2,5 m, Gába 1999).

A significant erosion in streambeds and valley bottoms occurred also in the mountain Carpathian section of the Morava river catchment (Bečva river). The watercourses transported a great amount of gravel sediments, which frequently filled up the existing streambeds (e.g., the Dolní Rozpitý brook in the Dolní Bečva river - Rožnovská brázda /Rožnov furrow/). The upper sections of mountain watercourses eroded down to the fresh parent rock, and significant erosion cuts formed. The strong lateral erosion of the Rožnov Bečva river in Rožnov p. R. denuded a unique geological outcrop with a specimen of a tectonic contact of flysch layers (Kirchner, Krejčí 1998a). A significant surface erosion and the removal of the top layer of flood plain

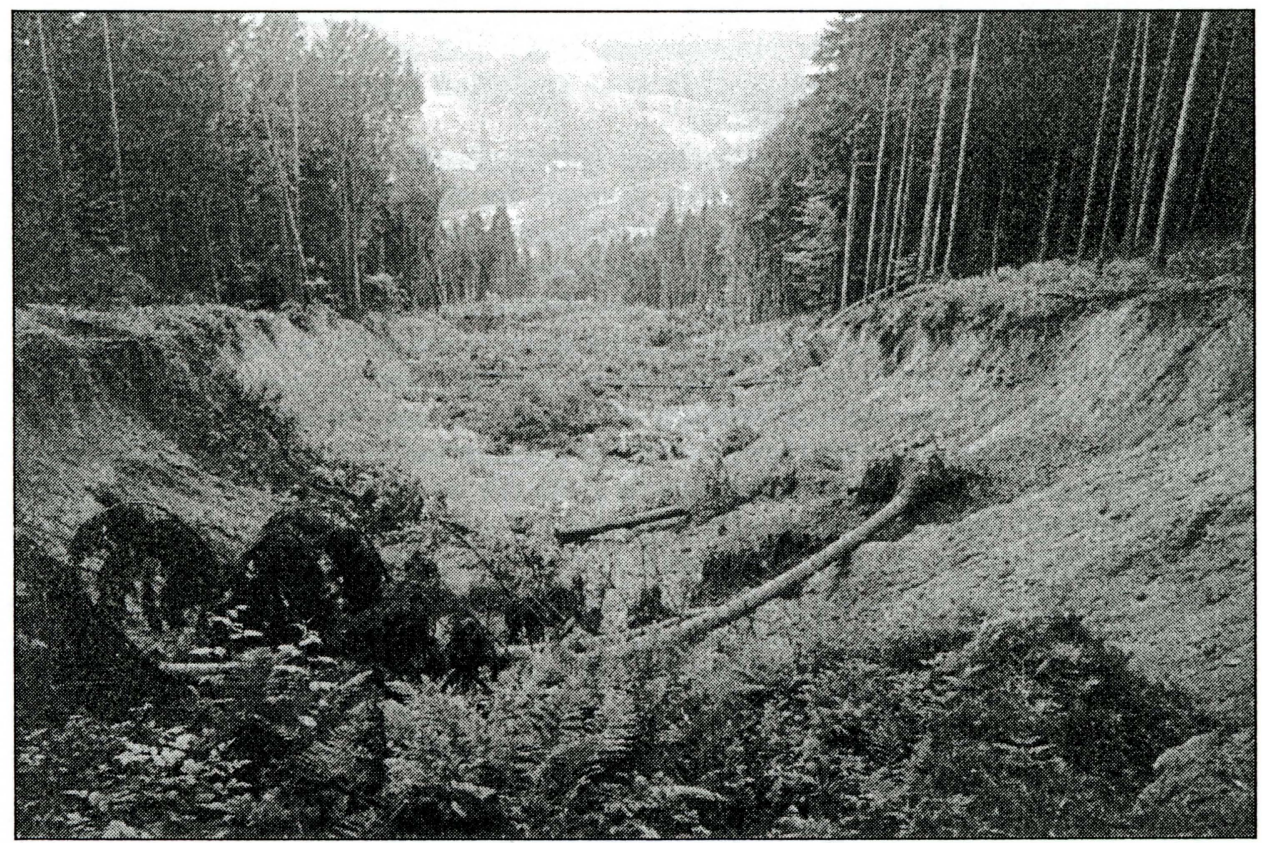

Fig. 3 - Example of a landslide in the cadaster of the Bystřička village (photo by $\mathrm{K}$. Kirchner) 
sediments took place in the flatter relief of the catchment in the upper and lower reaches of the Bečva river. Two levels of streambed formed, the lower the active one, and the higher - the flood streambed. An extensive flood effusion and the transformation of the flood wave in the flood plain occurred in the middle and lower sections of the Morava river. A great amount of finegrain sediments deposited in many places (e.g., the flood plain surface north of Olomouc). On the contrary, the erosion damaged flood protection dikes, sporadically the high buffer banks of the Morava riverbed retreated (e.g., the location Osypané břehy north of Strážnice).

Unlike the impacts on settlements and population, which are frequently almost catastrophic, the impacts on flora, fauna and biocenoses were by far not only adverse but in many cases the flood wave and the floods had positive impacts. To sum up, we can even say that the 1997 flood, whatever disastrous from the human point of view, had beneficial impacts as a natural and a very efficient revitalisation factor, particularly in the floodplains of Moravian rivers.

At the same time, it must be stressed that the close-to-nature ecosystems, or those being almost natural, particularly larger floodplain forests, had positive impacts on the course of the flood, also. So, for example, the floodplain forests in the protected landscape area Litovelské Pomoraví could significantly slow down the floodwave of the Morava river upstream of Olomouc. According to I. Machar (1997), the floodwave flowed through the local floodplain forests for a full ten hours. The large floodplain forests at the confluence of the Morava and Dyje rivers in the border area of the Czech Republic, Slovakia and Austria became a very significant retention space retaining more than $50 \mathrm{mil} . \mathrm{m}^{3}$ of flood water. This significantly contributed to mitigating the devastating course of the flood.

The devastating effects of the flood manifested themselves primarily in the non-close-to-nature ecosystems, particularly in the extensive agrocenoses. In terms of the forest stand, the flood wave primarily tore away the spruce monocultures set out unsuitably in the flood plains - as was the case in several locations along the rivers in the foot hills of the Hrubý Jeseník mountains. Among the riparian stand tornaway, the Euroamerican poplars (Populus canadensis) prevailed, while the autochtonous flood plain tree species forming the riparian stands were affected substantially less. On the contrary, the landslides activated by the disastrous precipitation manifested themselves in both spruce stands and the close-to-nature mixed forest stands as well as in the rich-in-species grasslands with scattered spruces.

In the flood plain forests, the flood affected the lower storeys, i.e. the shrub and herb layers. The mortality of the shrub layer of the European elder (Sambucus nigra) occurred in locations with longer-term flooding, in some locations this was also true of the young growth European ash (Fraxinus excelsior) and other flood plain tree species. In terms of the herb layer, primarily species with well-developed vegetation organs managed to renew their above-ground biomass by the end of the 1997 growing season - of the neophytes primarily Reynoutria japonica and Helianthus tuberosus, of the native species Urtica dioica. The research conducted so far has not confirmed the assumption that the species composition of the herb synusia will substantially change as a result of the oversedimentation of the soil surface by flood sludge and, in some locations, also by wood debris. Neither does the flood seem to have made a more significant contribution to the further dissemination of expansive neophytes. The main tree layer of the flood plain 
forests accepted the flood as one of the necessary conditions for its growth, that is as a positive factor.

As a matter of course, the mortality of animals occurred during the course of the flood, particularly that of the game. However, the survey in the Soutok reserve in southern Moravia suggested that most damage was inflicted to the non-original fallow deer (Dama doma). Generally, the roe deer population (Capreolus capreolus) and the brown hare population (Lepus europaeus) were affected most by the flood. The flood affected also small mammals in different ways. The common vole population (Microtus arvalis) that was originally a steppe vole decreased substantially. However, unlike this field pest, some rarer wetland species (such as Neomys anomalus and Apodemus agrarius) were not affected. The wetland survey carried out after the flood in the protected landscape area Poodři suggested that to the contrary, their populations increased.

The flood did not cause any serious threats to either aquatic ecosystems or populations and communities of aquatic organisms (Peňáz 1998). In the upper reaches, no conclusive changes in the structure of fish populations occurred, with the exception of the grayling (Thymallus thymallus). Some losses in fish population manifested themselves in lowland reaches since the water effused into field crops. However, the overall finding is that, after the flood, the aquatic ecosystems showed a high degree of regeneration. The flood extended the morphological diversity of aquatic biotops, also a prerequisite for an increase in the species diversity.

The significant negative phenomena caused by the flood include the mass outbreak of mosquitoes in southern Moravia, which occurred after the flood in depressions with a reduced run-off of effused waters. The warm summer weather also contributed to the growth of an abnormally strong mosquito population. As a result the inhabitants of Lanžhot and other villages were exposed to a mosquitoes for two or even more weeks after the flood was over (Pražák 1998).

Despite a series of direct negative effects and implications caused by the flood, it can be said that they were mostly temporary phenomena. From the long-term point of view, the impacts of the flood, particularly on the flood plain and riverine ecosystems, can be regarded as positive. The technically regulated watercourses were substantially revitalised even in long sections, with a diversified mosaic of biotops to be found in the riverbed, and a flood plain having formed in some locations. This phenomenon, which is positive from the environmental point of view, is striking particularly along the Bečva river between Valašské Meziříčí and Přerov. Some rare bird species could significantly increase their populations there (such as Alcedo athis, Riparia riparia and Charadrius dubius) as the flood created favourable biotops for their nesting. A favourable adaptive succession is taking place in the wide flood beds with denuded gravel banks. In the initial stages, some communities excluded from the flood plain landscape as a result of previous water management interventions, also appeared there, e.g., Saliceta gragilis (Lacina, Mackovčin, Kirchner, Hrádek, Řepka, 1998). With the mosaic of ecotopes newly created, or renewed respectively, by the flood, also the biodiversity, which was significantly reduced by antropogenous interventions, is again growing. Not only the six selected sections along the Bečva river, but also parts of the flood beds of other Moravian rivers should by declared protected zones and left up to natural development. These sections must be protected against attempts to bring them back into technically designed beds. 
They must be preserved not only as unique scientific study areas, but also as places that would remind those living in the flood plain landscape of the enormous strength and power of the flood, a natural landscape enhancement factor, which could return here again.

\section{Long-Term Flood Impacts on the Social System}

As has been said, the damage done by the flood to the economy has been mostly restored or its restoration is approaching the final stage. Secondary economic losses can hardly be separated from the implications of the regressive development of the Czech economy after 1997. However, in the course of research conducted so far we have not come across a case of a larger company going bankrupt as a direct result of the 1997 floods. Paradoxically, the flood may have contributed to revitalising a company going bankrupt for other reasons or to prolonging the time of its existence as a result of the mobilisation of human potential, the payment of damages, state aid or the obtaining of an order to remove flood damage. It is particularly small businessmen who came under real threat.

The infrastructure, particularly roads, railways and technical networks, but also social facilities, were heavily damaged. Taking advantage of this, a number of communities built new facilities to meet the present-day needs. In terms of infrastructure, the situation of some communities affected by the flood visibly improved even though many of them ran into debts or allocated funds for removing the impacts of the flood from other items.

The housing stock renewal was more complicated. Not all the damage was covered by insurance. The existing state-subsidy programmes did not cover

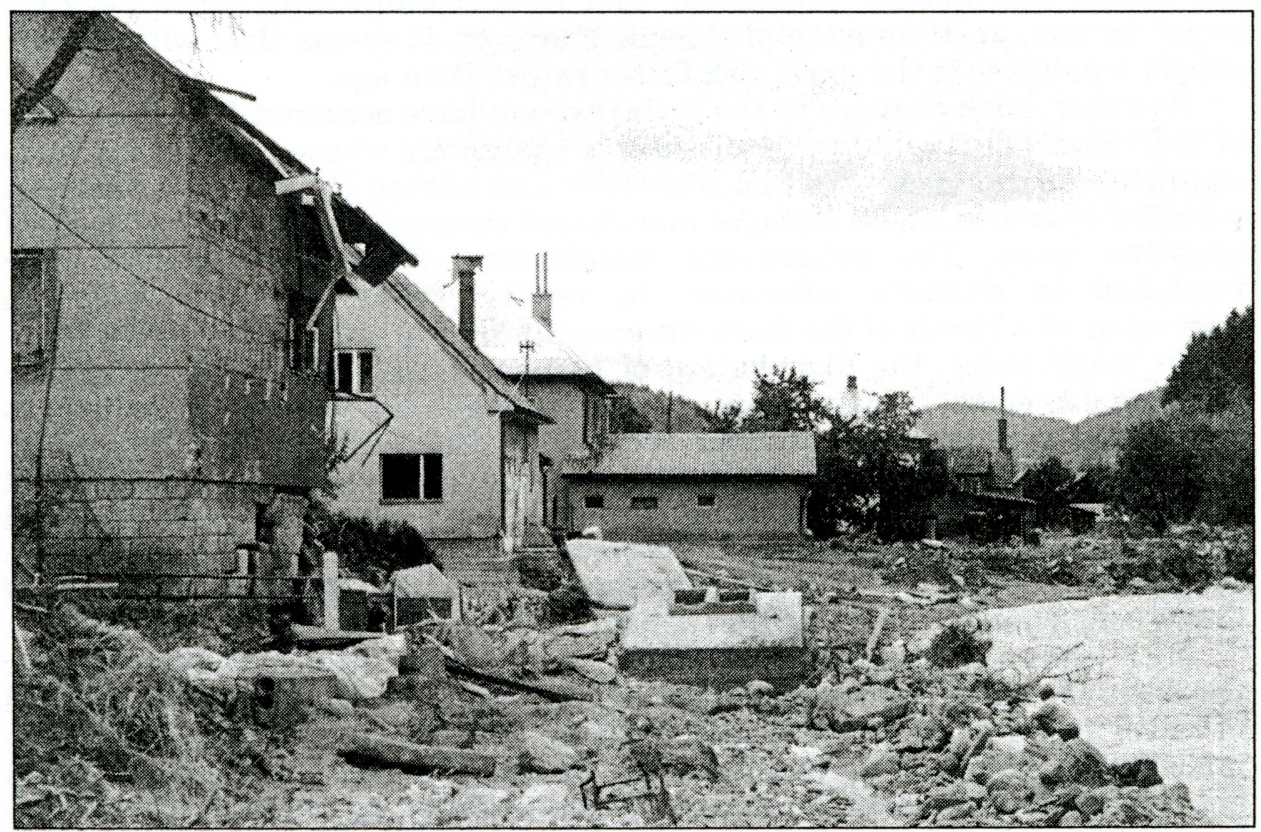

Fig. 4 - Structures damaged by the flood in the village of Bystřička (Photo by K. Kirchner) 
the new housing costs either in addition, they were based upon a strong participation of local people. The affected population divided into two basic groups. The first group was represented primarily by families at productive age who started to build new or repair old structures, as a rule with a big share of their own work and with incurring debt. Two years after the disaster, most of the structures are approaching completion. They will presumably provide a higher standard of housing than those in which these people lived before the flood.

The second group was represented primarily by elderly people who were no more able, either financially or physically and psychologically, to build or repair their homes, or it did not make sense from the economic point of view. Some communities constructed apartment houses for such people, these houses being styled as boarding houses or nursing homes. This is the case only in Troubky where 313 houses were destroyed and 386 seriously damaged. Despite the fact that the material standard of the elderly housing environment has typically improved, the change in the style of living may have adverse impacts on them.

So, we are getting to the most significant long-term social impact of the 1997 flood - the damage to humans (Vaishar, Lacina, Ondráček 1999). Death tolls or damage to health are naturally irreplaceable. Today, however there can be no doubt about the harmdone to the social and psychological health of the affected population either. These injuries can be seen at several levels. It may be a direct attack on the psychological condition of humans as a result of traumatising experiences known as post-traumatic stress disorder. They may experience depressive states caused, for example, by the loss of prospects in life, the awareness of powerlessness against nature forces or an enforced change in lifestyle. These symptoms are visibly manifested, particularly with the female and elderly population, and they combine with other negative social factors, such as unemployment. However, it seems that with elderly people loneliness is the main risk factor rather than age.

However, such changes in the social system have occurred. The behaviour of individuals facing hazard was a test of characters whose results may have significantly changed the social hierarchy and human interrelationships. As a matter of course, these changes manifested themselves in both positive and negative ways. The subsequent mobilisation of human potential has remained in citizen's memories. In reality, tendencies for population migration as a result of the flood were manifested in only exceptional cases.

In many cases, the distribution of humanitarian aid brought relatively considerable social controversies with it. People in the affected communities are still at war with one another because of their different opinions on its distribution. There are signals that in some communities citizens understood the distribution of aid as a trend to bring back state subsidies allocated according to completely different criteria than those reflecting the real affects of the flood (Premusová, 1999). The research on the social implications of floods continues by means of the methods of behavioural geography.

The historical awareness of flood hazards has returned as the basic precondition for preventing flood damage. Building authorities have adopted rules for erecting structures in flood zones, the reviews of town and country plans are in preparation, etc. However, despite this fact many citizens could not be prevented from building their houses in the flood zone again. In relation to population, the prevention is, as yet, focused on the warning system. What is most essential is the preparedness of the population. However, little 
consideration is still being given to this fact. During the 1997 floods, the communities in the lower sections of watercourses were warned, in many cases, many days ahead. However, it was frequently of little use when the concrete potential risks were not known and when the activities of authorities, institutions and individuals were not clearly defined. The inhabitants of communities affected by the 1997 floods are ready to leave their houses with any heavier rain. This attitude may easily turn into panic, which could have more or less adverse impacts in the case that the floods recur. In relation to the above-mentioned problems are also the legislative and organisational steps to be made to ensure that the rescue system works as required.

\section{Potential Flood Damage Protection Strategies}

In our opinion, there are three basic strategies to control flood damage, and, as a rule, they fit into the real world. They can be defined as a) geographical, b) technical and c) adaptive.

The geographical method is based upon selecting such locations for residential and other structures that are situated outside the flood zone, that is locations, which are under minimum risk for natural disasters. This method had been adopted by our ancestors as is obvious by the location of the old cores of our settlements and by the fact that these cores remained mostly unaffected by the floods in those communities hit by them. The question is to what extent we can return to this method at the present time. A certain potential in this respect is hidden in the development of individual transport and in the reduction of energy- and raw material-consumption in manufacturing, which would enable to locate some buildings in less accessible locations. However, this is in contradiction with the fact that the natural environment of the majority part of these areas is relatively well-preserved, making them less suitable for mass housing construction. Therefore, this method is suitable as a specific approach to new housing construction rather than as a universal approach.

In the course of the 20th century, technical methods were applied in the territory of the Czech Republic as almost the only way of controlling floods. They primarily include the construction of dams and embankments. However, these measures have economic limitations as it is obviously of no use to build dams and embankments for such a period that exceeds the life of the particular dam, and also environmental limits as they represent a serious intervention in the landscape, some carrying potential implications of which can hardly be predicted in full. Today, these measures also include some attempts to restore a more natural landscape management since and these measures also often mean technical interventions, they require substantial financial means and bear the risks of unpredictable implications for the landscape. Thus, the application of technical methods is also limited although it is becoming more and more popular.

The third option is to reckon with flood risks. That means to construct structures that would stand the floods for a certain period of time without being seriously damaged, to manage catchment areas so that the impact of the eventual flood wave is minimised, and to design a system of prevention, warning and population preparedness so that no threats to life emerge and losses in property are minimised. This must be preceded by a series of legislative, organisational and economic measures. 
The scientific research generally and the geographical research particularly have their place in the system of prevention. The issue of natural risks is also discussed in great detail in Czech geography (e.g., Hrádek 1995), and the 1997 floods have made it an issue of common concern. The human geography, in turn, will find its place in the research on the regionally-based perception of these risks, the possible impacts of flood situations on the settlement, economy, infrastructure and the social system and in the research on measures to prevent them.

\section{Conclusion}

We are aware of the fact that, in terms of the size of the affected area, the death tolls or the volume of material damage of the 1997 floods in Moravia cannot be compared to those hitting people elsewhere in the world. Of all of them, let us mention at least the relatively regular floods in Bangladesh or those that caused the shocking death tolls in Venezuela in late 1999. In any case for the affected population of Moravia, these experiences were as traumatising as for people elsewhere in the world.

From the point of view of research, it may, however, be an advantage that regarding the current situation in the Czech Republic, we can draw our attention to detail. Although natural and social conditions differ considerably in various parts of the world, one of the essential causes of the catastrophic impacts of floods is identical: the location of settlements in places unsuitable for housing construction from the point of view of natural risks. In this respect, we would gladly exchange experience with foreign experts.

\section{Literature:}

DIKAU, R., BRUNSDEN, D., SCHROTT, L., IBSEN, M. L., eds. (1996): Landslide Recognition, Identification, Movements, and Causes. John Wiley \& Sons, Chichester, $251 \mathrm{p}$.

GÁBA, Z., GÂBA, Z. junior (1997): Povodeň z července 1997 jako přírodní jev. Severní Morava, 74, Sumperk, pp. 5-30. The July 1997 Flood as a Natural Phenomenon.

GÁBA, Z. (1999): Geologické poznatky $\mathrm{z}$ povodně v červenci 1997 (Jesenická oblast). Geologické výzkumy na Moravě a ve Slezsku v r. 1998. VI., ČGÚ, pobočka Brno, katedry geologických věd PřF MU, Brno, pp.142-144.

HLADNY, J. et al., eds. (1998): Vyhodnocení povodňové situace v červenci 1997. Ministerstvo životního prostředí ČR Praha, 163 p.

HRÁDEK, M., ed.: (1995): Natural Hazards in the Czech Republic. Regiograph, Brno, $161 \mathrm{p}$.

KIRCHNER, K., KREJČÍ, O. (1998a): Charakteristika jevů způsobených extrémními srážkami v roce 1997 na Vsetínsku: návrhy řešení zpưsobených škod. Geologické výzkumy na Moravě a ve Slezsku v roce 1997, 5, ČGÚ - pobočka Brno, katedry geolologických věd Pṛ̌ MU Brno, ČGS, 1998, pp.103-108.

KIRCHNER, K., KREJČÍ, O. (1998): Slope movements in the flysch Carpathians of eastern Moravia (Vsetín district) triggered by extreme rainfalls in 1997. Moravian Geographical Reports, 6, No.1., pp. 43-52.

LACINA, J., MACKOVČIN, P., HRÁDEK, M., KIRCHNER, K., ŘEPKA, R. (1998): Sledování sukcese vegetace a vývoje říčního koryta ve vybraných profilech spojené Bečvy mezi Osekem n. B. a Valašským Meziřrićím. Výzkumná zpráva. Ustav geoniky AV ČR a Agentura ochrany př́rody a krajiny ČR, Brno, $61 \mathrm{p}$.

MACHAR, I. (1997): Katastrofální povodeň v Litovelském Pomoraví. Ochrana přírody, 52 No. 9, p. 265-268.

MUNZAR, J., ONDRÁČEK, S., TÁBORSKÁ, J. (1997): Disastrous floods in Moravia and Silesia in July 1997. Moravian Geographical Reports, 5, No. 2, p. 44-59. 
MUNZAR, J. (1998): Historical floods in Bohemia and Moravia on the example of the year 1598. Moravian Geographical Reports, 6, No. 2, p. 50-58.

PEŇÁZ, M. (1998): Společenstva obratlovcủ a povodně. Veronica,12, a special issue, pp. 42-42.

PRAŽÁK, O. (1998): Záplavy a komáři na Břeclavsku v roce 1997. Veronica,12, a special issue, p. 44-45.

PREMUSOVÁ, J. (1999): Vlastnictví jako interpretační klíč k povaze územního společenství. Sociologický časopis, 35, No. 1, pp. 101-110.

RYBÁR, J., STEMBERK, J., SUCHY, J. (1998): Cut-off a railway line by earth flows in the Czech Republic during July 1997. 8th International IAEG Congress,. Balkema. Rotterdam. pp. 2083-2089.

VAISHAR, A. (1999a): Povodně, krajina a lidé v povodí řeky Moravy I. Regiograph, Brno, $81 \mathrm{p}$.

VAISHAR, A. (1999b): Floods in Moravia 1997 and regional development. In: Hlavinková, P., Munzar, J. (eds.): Regional prosperity and sustainablity. Regiograph, Brno, pp.192200.

VAISHAR, A., LACINA, J., ONDRÁČEK, S. et al. (1999): Floods in the Morava river basin in 1997 and their consequences for the social system. Moravian Geographical Reports, 7, No. 2, pp. 2-11.

VÍT, J., AICHLER, J., PECINA, V. (1998): Červencová povodeň v oblasti Jeseníků - příčiny, průběh a následky. Geologické výzkumy na Moravě a ve Slezsku v r. 1997. ČGÚ, pobočka Brno, katedry geologických věd PřF MU, 5, Brno, pp.118-122.

\section{Shrnutí}

\section{DLOUHODOBÉ NÁSLEDKY POVODNÍ 1997 V POVODÍ ŘEKY MORAVY}

V létě 1997 byla větší část povodí Moravy spolu s povodím Odry a částečně i Labe postižena extrémními dešti, které nemají co do množství srážek a rozsahu postiženého území obdoby po celou dobu klimatologických a hydrologických měření. Tyto srážky vyvolaly povodně, v jejichž př́mém dủsledku zahynulo 50 lidí a materiální škody dosáhly asi 60 miliard Kč. Většina přímých škod již byla nahrazena. Vynořila se ale otázka dlouhodobých následků povodní. Tuto problematiku studuje skupina geografů a sociologů na př́ípadových studiích ve čtyřech vybraných modelových oblastech.

Modelová oblast Hanušovice / Jindřichov se nachází na horním toku řeky Moravy. Dnešní sídla včetně průmyslových podniků a infrastruktury jsou lokalizována v hlubokých úzkých údolích. Oblast byla postižena na počátku povodně mohutnými přívalovými vlnami se značným ničivým účinkem a byla po několik dnů odříznuta od světa. Modelová oblast Mikulůvka / Bystřička / Růždka se nachází v povodí Bečvy a jejího přítoku Bystřice. Na tomto toku byla vybudována přehrada, která v průběhu povodní 1997 přetekla a ohrozila sídla pod sebou. Povodeň kromě toho iniciovala četné sesuvy, které nebyly dodnes stabilizovány. Modelová oblast Bochoř / Troubky / Vlkoš se nachází v ploché krajině Hornomoravského úvalu. Byla postižena vylitím relativně vzdálené řeky Bečvy, takže povodeň přišla $\mathrm{z}$ nečekaného směru. Plochá krajina neposkytovala možnost útočiště. Značná část domů byla postavena z nepálených cihel, které neodolaly dlouhodobému pobytu ve vodě. Ve zř́cených domech nalezlo smrt 9 obyvatel obce Troubky. Modelová oblast Otrokovice představuje středně velké město na soutoku Moravy a Dřevnice, jehož část byla postavena ve 30 . letech přímo v zátopové zóně. Velkorysá protipovodňová ochrana technického charakteru neodolala náporu tř́ povodňových vln $\mathrm{z}$ obou řek a $\mathrm{z}$ rozlivového jezera po vylití řeky Bečvy. Město bylo zaplaveno do výše více než 3 metrů po dobu několika týdnů.

Společným jmenovatelem povodňových škod byla výstavba sídel v zátopových územích. Existující ochrana pomocí přehrad a hrází se ukázala být při extrémní hydroklimatické situaci nedostatečnou. Vedla však k zániku historické paměti, vztahující se k nebezpečí povodní. Snížení retenční schopnosti krajiny nevhodným způsobem hospodaření mohlo zřejmě pouze oddálit nástup povodňových vln. Povodněmi byla těžce poškozena infrastruktura, bytový fond, průmyslové i zemědělské podniky. Sekundární ekonomické ztráty nelze oddělit od ztrát, připadajících na vrub ekonomickým problémům Česka v roce 1997 a následujících. Cást infrastruktury a obytných objektů byla rekonstruována nebo postavena znovu a přinesla tak novou kvalitu. V sociálním systému tak přetrvávají především škody na lidech, k nimž došlo ve sféře sociální i psychické. Poststressový syndrom nabývá někdy až kli- 
nického charakteru. Staří a osamělí lidé, kteří již nemohli postavit nové domy a museli se uchýlit do penzionů a domů s pečovatelskou službou, se již těžce adaptují na změněný životní styl, byt’ se technická úroveň jejich zabezpečení zlepšila. Došlo k narušení sociální hierarchie a sociálního systému. Projevilo se narušení mezilidských vztahů v důsledku různých názorů na rozdělování humanitární pomoci, ale i závisti nad novými a opravenými domy, jejichž výstavbu nebo rekonstrukci umožnila výplata pojistného nebo státní podpora.

Navrátilo se historické vědomí nebezpečí povodní jako základní předpoklad prevence. Zbývá však učinit řadu kroků na poli legislativním, ekonomickém i organizačním. Málo pozornosti se věnuje přípravě obyvatelstva na zvládnutí krizových situací, což je zřejmě důležitější než systém včasného varování. Existují tři základní strategie ochrany před povodňovými škodami. Geografická metoda spočívá ve výběru lokalizace objektů mimo předpokládané zátopové zóny, technická metoda je založena na výstavbě přehrad, ochranných hrází a dalších zařízení, zatímco adaptační připouští postižení objektů povodněmi a snaží se minimalizovat jejich následky. V reálné situaci půjde zpravidla o kombinaci uvedených metod, $\mathrm{z}$ nichž každá má své bariéry a rizika.

Obr. 1 - Povodí Moravy v rámci území Česka

Obr. 2 - Vybraná modelová území: 1 - Hanušovice / Jindřichov, 2 - Bystřička / Mikulůvka / Růždkka, 3 - Bochoř / Troubky / Vlkoš, 4 - Otrokovice.

Obr. 3 - Př́lklad sesuvu v katastru obce Bystřička (snímek K. Kirchner)

Obr. 4 - Povodní poškozené objekty v obci Bystřrička (snímek K. Kirchner)

(Authors are with Ústav geoniky AV ČR, pobočka Brno, PO Box 23, 61300 Brno, Czechia, e-mail: geonika@geonika.cz.)

Arrived to the editor's office on January 15, 2000 